\title{
An Evaluative Study on Sidoarjo Mud Flow after Phytoremediation Treatment in Milk Fish (Chanos Chanos) Liver
}

\begin{abstract}
A sudden discharge of Sidoarjo mud flow into the water bodies would disturb aquatic biota, the fisheries culture. The aim of this research is to evaluate the availability of phytoremediated water of Sidoarjo mud flow (abbreviated: pwmf) as a milkfish culture media using liver histological approach. After two weeks acclimatization period, the juvenile and adult of milkfish were exposed the pwmf at the sub lethal concentration and an acute static bioassay at 96 hours. Control fishes were reared in the artificial brackish water. Each treatment of pwmf exposure was done in three replicates. After exposure, the liver fishes were removed and histologically processed using paraffin method and HE staining. Histopathology change was assessed semi quantitative scoring. The result of the histological analyses suggested the liver pathological features such as vacuolation of hepatocytes, the loss of sinusoid integrity from mild to severe occurrence and necrosis.
\end{abstract}

Dewi Hidayati ${ }^{1}$
Keywords-histopathology, liver phytoremidiation, milkfish

\section{INTRODUCTION}

Cince 29 May 2006, a mud volcano has been emitting $\checkmark$ hot mud in the Sidoarjo district of East Java, Indonesia. Mud volcanoes are geological phenomena due to over pressurized, subsurface mud layers. The mud volcano in the Sidoarjo district emits mud at an average rate of more than $40.000 \mathrm{~m}^{3} /$ day [1]. A Sudden discharge of Sidoarjo mud flow into the water bodies would harm aquatic biota, including the fisheries culture. The one of recommendation of UNDAC 2006 is to determine re-usability of the mud.

Preliminary research showed the mixture of mud flow and fresh water in ratio 1:1 ratio that treated by one week phytoremediationusing Salvinia molesta could reduce Cd and $\mathrm{Cr}$ content $50 \%$ [2]. This phytoremediated water of Sidoarjo mud flow (abbreviated: pwmf) needed to be evaluated before it is used as an aquaculture media.

Histopathological biomarkers can be used as indicators of the effects on organisms of various anthropogenic pollutants and are a reflection of the overall health of the entire population in the ecosystem. The alterations in cells and tissues in vertebrate fish are recurrently used as biomarkers in many studies, but such changes occur in all vertebrates and invertebrates inhabiting aquatic basins. Histopathological biomarkers embody tissue lesions arising as a result of a previous or current exposure of the organism to one or more toxins. Welldocumented lesions based on experimental data in liver, ovary, skeleton system and skin have been used as biomarkers [3]. Liver is the detoxifticator and biotrans-

${ }^{1}$ Dewi Hidayati is with Department of Biology, FMIPA, Institut Teknologi Sepuluh Nopember, Surabaya, 60111, Indonesia. E-mail: d_hidayati@bio.its.ac.id. formator organ, and liver is also found to be the most sensitive organ to the water contamination $[4,5]$. The liver is a target for many toxicants, and it receives toxic substances both from intestinal and branchial routes, because of its central location in the circulatory system of vertebrates [14].

According to Guilio and Hinton (14) there are three major functions of the liver essential for life of the organism. Firstly, it functions as metabolism, storage, and redistribution of nutrients and other endogenous molecules: the synthetic and excretory functions of the liver maintain the homeostasis of the organism [14]. To achieve this, specific molecules are synthesized in hepatocytes, packaged in the. Golgi apparatus, transported in a specific direction released into the intercellular spaces and to the bloodstream, where they are taken up by other organs and utilized. Some examples of storage, synthesis, and redistribution functions including glycol-genolysis and hepatocyte release of glucose to govern blood glucose levels; hormone synthesis and release (e.g., somatomedins); synthesis and release of proteins, as in the case of serum albumins, the yolk precursor vitellogenin, and the zona radiata protein or choriogenin. The removal, metabolism, and eventual excretion of compounds also participate in the homeostatic role of the liver; for instance, hormones are taken up and broken down by the liver. Secondly, it is used in metabolism of lipophilic compounds, including xenobiotics: biotransformation reactions catalyze the conversion of endogenous as well as exogenous compounds with poor water solubility to more hydrophilic metabolites that can be readily excreted. With respect to xenobiotics, the majority of hepatic biotransformation reactions may be considered as a detoxification process decreasing toxic body burden by enhancing excretion. However, during the biotransformation process, generation of electrophilic reactive species can lead to interaction with basic cellular constituents such as DNA and proteins. The end result of this process may be disruption of normal cellular function and overt toxicity, including acute forms and chronic states such as carcinogenesis and tumor formation. Thirdly, it helps formation and excretion of bile. Bile excretion is important for the elimination of degradation products of endogenous compounds such as heme or steroid hormones, as well as for the elimination of xenobiotics and their metabolites and some metals such as copper and mercury.

Milkfish (Chanos chanos) or commonly called "Bandeng" is one of the fishery products in Sidoarjo that has a high economical value. The aim of this research is to evaluate the availability of phytoremediated water of Sidoarjo mud flow (abbreviated: pwmf) as a milkfish culture media using liver histological approach. 


\section{METHOD}

\section{A. Preparation Treatment Media}

The mud sediment was obtained from Sidoarjo mud pond area as shown at Fig. 1, at coordinate $7^{\circ} 31^{\prime} 40.07^{\prime} \mathrm{S}$ dan $112^{\circ} 42^{\prime} 14.49^{\prime} E^{\prime}$.

The watery mud was mixed with fresh water with ratio $1: 1$, and treated by $S$. molesta phytoremediation. The product of phytoremediation was called phytoremediated water of Sidoarjo mud flow (abbreviated: pwmf). Finally, this Pwmf media was used as treatment media. Pwmf media was separated in two kinds of treatment media: one media without mud sediment and the other one contained mud sediment. Each treatment media was measured to check the parameters that are suitable with limiting factor to the biological of fish, such as, heavy metal: $\mathrm{Cd}$ and $\mathrm{Cr}$ that measured by AAS (Atomic Absorption Spektro-fotometer) SHIMADZU Home 210 VGP. Turbidity was analyzed with turbid meter, sulfur and Nitrate were measured with Spectrophotometer.

\section{B. Preparation Animal Test}

Young adult milkfish (C. Chanos) were obtained from a milkfish farm in Gresik, East Java. Before released into mud, every ten fish was acclimated in $40 \times 30 \times 30 \mathrm{~cm}^{3}$ aquarium filled with 20 liters of brackish water for 2 weeks. Fish was aerated and fed with commercial fish food. Water was filtered and its qualities were checked weekly. DO meter was used to check dissolved oxygen; and salinity was controlled using rephractometer.

\section{Treatment}

After two weeks acclimatization period, the juvenile and adult milkfish were exposed to pwmf at the sub lethal concentration and an acute static bioassay at 96 hours. The treatment was separated in four treatments and one control. The four treatments consist of: pwmf without mud sediment and the pwmf that contained mud sediment. Meanwhile the control fish was held in the artificial brackish water. Each kind of treatment was done in three replicates. After exposure, the liver of milkfish was removed and brought to histological process using paraffin methods and Hematoxylin eosin staining.

Histopathological alteration was assessed semiquantitative using a score ranging from $(-)$ to $(+++)$ depending on the degree and extent of the altera-tion: $(-)$ none, $(+)$ mild occurrence, $(++)$ moderate occurrence, $(+++)$ severe occurrence $[11,13]$.

Semiquantitave scoring is determined according to the width of histopathological alteration occurrence in the liver lobules as shown in Table 1.

\section{RESULT AND DISSCUSSION}

\section{A. Result}

The result of physical and chemical content measurement is shown in Table 2 presenting the metal content in pwmf. It shows the concentration of $\mathrm{Cd}$ in pwmf containing $0.020 \mathrm{mg} / \mathrm{L}$ sediment and $0.50 \mathrm{mg} / \mathrm{L} \mathrm{Cr}$. It indicates that $\mathrm{Cod}$ and $\mathrm{Cr}$ in the pwmf containing sediment are above the recommended Water Quality Criteria (WQC) according to EPA 2005 and 2010 revision (approved by EPA Region 10). WQC has recommended that the acute concentration of $\mathrm{Cd}$ and
Cr for aquatic life should range between $0.0039 \mathrm{mg} / \mathrm{L}$ and $0.016 \mathrm{mg} / \mathrm{L}$, respectively.

It is figured out from the study that $\mathrm{Cd}$ content in pmwf with mud sediment is $0.02 \mathrm{mg} / \mathrm{l}$, and $\mathrm{Cr}$ is $0.5 \mathrm{mg} / \mathrm{l}$. According to the PP RI No.20 tahun 1990, a limited content of $\mathrm{Cd}$ for $\mathrm{C}$ tegory (for fisheries and veterinary) should be $0.01 \mathrm{mg} / \mathrm{l}$ therefore, it is presumed that $\mathrm{Cd}$ becomes one of the histopathological factors.

Observed turbidity in pwmf that contain sediment is 6716 NTU, which also indicates above recommended water quality for maintaining native fish populations. Random monthly values should never exceed 100 NTU, hence it is also predicted to have contribution of to liver histopahological occurrences [17].

The result of the liver histological analyzing suggests that the milkfish exposed to the phytoremediated water mud flow (pwmf) without mud sediment will indicate the mild liver pathological features, such as vacuolation of hepatocytes and lost of sinusoid. Meanwhile, the milkfish exposed to the pwmf will show severe pathological liver, such as: edema cell and lost of sinusoid in the most of part of liver tissue.

Degeneration of the hepatocyte in liver tissue of treatment milkfishes is indicated by detoxif ication. Indirectly, it is indicated if there are some toxic matters from the mud. Meanwhile, the fish treated with pwmf without sediment also shows the liver degeneration although the $\mathrm{Cd}$ content in this media had reduced untill $0.00 \mathrm{mg} / \mathrm{l}$. Due to these reasons, it is presumed that if there is other potential contaminant in the mud flow that is not measured in this present research. Other pollutant that has possibly made liver hepatocyte degeneration is Polyaromatic Hydrocarbon (PAHs) [6]. UNDAC reported in 2006 that the concentrations of benzene and toluene elevated at the source and the "exposure" location. Xylenes and hydrocarbons were also elevated [1].

Besides metal content, pwmf that contained mud sediment contain light mud particulate could inhibit the respiration rate. The mud particle would cover the gill respiration surface. So that, the intaken oxygen into body cells including hepatocyte (liver cells) will decrease. Recent evidence indicates that increases in oxidative stress and associated biochemical alterations could become a toxic mechanism in fish [7].

The presence of oxygen is very important to body recovery. Then, the histopathological of milkfish in this research is probably proceeded in three ways: the direct effect of metal that causes cytotoxicity in hepatocyte; indirectly by the decreasing of the energy source (oxygen) and combination both of them.

The histopathological semiquantitative analysis of the liver fishes that exposed by pwmf with mud showed more severe histopathological alterations than pwmf without mud (Table 3). All the treatment fishes suffered the hepatocytes vacuolation and loss of sinusoid integrity. Occurency of mud increasing these alterations. The vacuolation of hepatocytes was indicated with enlargement of the cell, so this abnormal hepatocytes (see star symbol at Table 2) showed larger size than the normal hepatocytes. Cell disturbances caused chemicals in the water and decreased oxygen intake caused by highly of turbidty in Sidoarjo mud water. 
Metal content in the water mud is predicted as a factor of degeneration in liver tissue. Protein inclusion bodies are common in metal toxicities [7]. Cellular swelling occurs either directly by denaturation of volume regulating ATPases or indirectly by disruption of the cellular energy transfer processes required for ionic regulation [8]. The histological changes identified within the hepatocytes in this $\mathrm{Cd}$ and $\mathrm{Zn}$ toxicity study result of various biochemical lesions [1]. Vacuolation of hepatocytes are associated with the inhibition of protein synthesis, energy depletion, disaggregation of microtubules, or shifts in substrate utilization [8].

Recent evidence indicates that increases in oxidative stress and associated biochemical alterations could be a toxic mechanism in fish exposed to pulp mill effluent [9]. Ultrastructural examination of winter flounder liver from clean and contaminated sites revealed a loss of hepaticglycogen and lipid stores with increasing environmental contamination, with a concomitant increase of abnormal proliferated endoplasmic reticulum (ER). Fluid accumulation in the cisternal space of the ER, and the perinuclear space and mitochondria led to vesicle formation. These vesicles coalesced, to form large cellular vacuoles that compressed the nucleus and residual cytoplasm to the margins of the cell. Vacuolation appeared to be a process that affected preductular cells, hepatocytes, cholangiocytes, neoplastic cells, and exocrine pancreatic cells [12].

The existing of enlargement of vacuolation hepatocytes in the liver tissue would insist the existence of sinusoid. So, the sinusoid will loss their integrity. Occurrence of mud also increasesing contaminant, which causes the vacuolated hepatocytes going to necrotic. As sinusoidal lining cells separate blood from liver mesenchyma, destruction of sinusoids should lead to hemorrhage. According to this interpretation, hepatocyte death is secondary to sinusoid destruction, hemorrhage in liver and hepatocyte apoptosis [17].

According to the functions of liver, hepatocyte vacuolezation and necrotic could lead the disturbance of some important physiological activities in fish, such as: inhibition of protein and hormone synthesis, decreasing of fish to detoxification process and inhibit formation, excretion of bile which is important for the elimination of degradation products of endogenous compounds [14]. This physiological disturbance would be generated to other abnormality including the growth, reproduction and immune system. Hence it would be affected the milkfish productivity.

\section{CONCLUSION}

Although the phytoremediation had proven to reduce the pollutant, such as heavy metal $\mathrm{Cd}$ and $\mathrm{Cr}$, the histological study indicated if the pwmf was not available yet as culture media. The liver pathological features that observed are vacuolation of hepatocytes, the lost of sinusoidal integrity and necrotic cells from mild to severe occurrence.
The further studies such as: analyzing mud pollutant and it's toxicity and improvement the water product of pwmf are still needed.

\section{REFERENCES}

[1] UNDAC, 2006, "Environmental assesment hot mud flow East Java Indonesia", Technical Report United Nation Disaster Assesment and Coordination (UNDAC) mission Juni-July. 2006, United NATION.

[2] Hidayati, D. Aunurohim, I. Krismurwani, A. Permatasari, 2009, "Phytoremediation potential of Salvinia molesta and Eichornia crassipes in the water that contaminated by Sidoarjo mudflow", Proceeding of The International Conference of Biological Science (ICBS) Gadjah Mada University.

[3] D. E. Hinton, P. C. Bauman , G. R. Gardner, W. E. Hawkins, J. D. Hendricks Muerchelano R. A. \& M. S. OIKIHIRO, 1985, "Histopatological biomarkers". In: RAND, G. M.

[4] Van Der Oost , R, BEYER, J, Vermeulen, NPE 2003, "Fish bioaccumulation and biomarkers in environmental risk assessment", A review, Environ Toxicol Pharmacol. Vol. 13, pp. 57-14.

[5] E. L. Rodrigues \& E. Fanta, 1998, "Liver histopathology of the fish Brachydanio rerio after acute exposure to sublethal levels of the organophosphate Dimetoato 500", Revista Brasileira de Zoologia, Vol. 15, pp. 441-450.

[6] S. Chang, V. S. Zdanowicz and R. A. Murchelano, 1998, "Associations between liver lesions in winter flounder (Pleuronectes americanus) and sediment chemical contaminants from north-east United States estuaries", -, ICES Journal of Marine Science, Vol. 55, pp. 954 - 969

[7] Cheville, 1994, N.F. Cheville, "Pathology: An Introduction to Interpretation", Iowa State University Press, Ames.

[8] D.E. Hinton and D.J. Laurén, 1990, "Integrative histopathological effects of environmental stressors on fishes", Am. Fish. Soc. Symp. 8, pp. 51-66.

[9] K. D. Oakes \& G. J.Van Der Kraak, 2003, "Utility of the TBARS assay in detecting oxidative stress in white sucker (Catostomus commersoni) populations exposed to pulp mill effluent", Aquatic Toxicology, 63(4), pp. 447-463.

[10] J. C. Van Dyk, G. M. Pieterse and JHJ van Vuren, 2007, "Histological changes in the liver of Oreochromis mossambicus (Cichlidae) after exposure to cadmium and zinc", Journal Ecotoxicology and Environmental Safety, Vol: 66, Issue 3, March, pp. 432-440.

[11] Knodell R.G., Ishak K.G., Black W.C., et. al.. 1981, "Formulation and application of a numerical scoring system for assessing histological activity in asymptomatic chronic active hepatitis". Hepatology.; 1, pp. 431-435.

[12] Moore Michael John, 1991, "Vacuolation, proliferation and neoplasia in the liver of Boston Harbor winter flounder (Pseudopleuronecte americanus)", Woods Hole Scientific Community.

[13] S. Thophon, M. Kruatrachue', E. S. Upatham, P. Pokethitiyook, S. Sahaphong and S. Jaritkhuan, 2002, "Histo-pathological alterations of white seabass, Lates calcarifer, in acute and subchronic cadmium exposure, Environmental".

[14] Pollution Journal, Volume 121, Issue 3, March 2003, pp. $307-$ 320.

[15] R. Giulio, and D.E. Hinton, 2008, "The toxicology of fishes”, published by Taylor \& Francis Group, LLC CRC Press is an imprint of Taylor \& Francis Group, an Informa business.

[16] K.H. Barnes, J.L. Meyer, and B.J. Freeman, 1998, "Sedimentation and Georgia's fishes: An analysis of existing information and future research", 1997 Georgia Water Resources Conference, March 20-22, 1997, the University of Georgia, Athens Georgia

[17] US EPA, 2005, National Recommended Water Quality Criteria EPA approved June 1, 2010.

[18] Jodo.S, Kungs.J, Chan,V.D, Kobayashi,S, Tateno, M, Lafyatis R, Teju, S. 2002, "Anti-cd95-induced lethality requires radioresistant $\mathrm{fc}_{\mathrm{rii}}{ }^{+}$cells , A novel mechanism for fulminant hepatic failure", The Journal of Biological Chemistry, 278, pp. 7553-7557. 
TABLE 1.

DESCRIPTION OF SEMIQUANTITAVE SCORING

\begin{tabular}{lll}
\hline $\begin{array}{l}\text { Semi } \\
\text { Quantitative } \\
\text { Scoring }\end{array}$ & Status & $\begin{array}{l}\text { Description of Histopathology } \\
\text { Alteration Occurrences }\end{array}$ \\
\hline- & None & no occurrences \\
+ & $\begin{array}{l}\text { mild } \\
\text { occurrence }\end{array}$ & $\begin{array}{l}\text { occurred in one third to two } \\
\text { thirds of lobules }\end{array}$ \\
++ & $\begin{array}{l}\text { moderate } \\
\text { occurrence }\end{array}$ & $\begin{array}{l}\text { involvement of one third to } \\
\text { two thirds of lobules }\end{array}$ \\
+++ & severe & $\begin{array}{l}\text { involvement of greater } \\
\text { than two thirds of lobules or } \\
\text { nodules }\end{array}$ \\
\hline
\end{tabular}

TABLE 2.

THe Result of Physic and Chemical Analysis of PWMF THAT USED As TREATMENT MEDIA

\begin{tabular}{lll}
\multirow{2}{*}{ Parameters } & \multicolumn{2}{c}{$\begin{array}{r}\text { Concentration of Physic-Chemical } \\
\text { Substances }\end{array}$} \\
\cline { 2 - 3 } & $\begin{array}{l}\text { Pwmf } \\
\text { without Mud } \\
\text { Sediment }\end{array}$ & $\begin{array}{l}\text { Pwmf with } \\
\text { Mud Sediment }\end{array}$ \\
\hline Cadmium & $0.00(\mathrm{mg} / \mathrm{l})$ & $0.020(\mathrm{mg} / \mathrm{l})$ \\
Chromium & $0.00(\mathrm{mg} / \mathrm{l})$ & $0.500 \quad(\mathrm{mg} / \mathrm{l})$ \\
Turbidity & $3.99 \mathrm{NTU}$ & $6716 \mathrm{NTU}$ \\
Sulfur & $0.00(\mathrm{mg} / \mathrm{l})$ & $0.000(\mathrm{mg} / \mathrm{l})$ \\
Nitrat & $0.37(\mathrm{mg} / \mathrm{l})$ & $1.600 \quad(\mathrm{mg} / \mathrm{l})$ \\
\hline
\end{tabular}

TABLE 3 .

SEMIQUANTITATIVE ANALYSIS OF LIVER HISTOPATHOLOGY OF TREATMENT FISHES

\begin{tabular}{|c|c|c|}
\hline \multirow{2}{*}{$\begin{array}{l}\text { Histopathological } \\
\text { Alteration of Liver }\end{array}$} & \multicolumn{2}{|c|}{$\begin{array}{l}\text { Semiquantitave } \\
\text { Scoring }\end{array}$} \\
\hline & $\begin{array}{l}\text { Pwmf Without } \\
\text { Mud Sediment }\end{array}$ & $\begin{array}{c}\text { Pwmf With Mud } \\
\text { Sediment }\end{array}$ \\
\hline Hepatocytes vacuolation & + & +++ \\
\hline Loose of sinusoid integrity & + & +++ \\
\hline Necrosis & - & + \\
\hline
\end{tabular}

TABLE 4.

THE LIVER OF CONTROL FISH

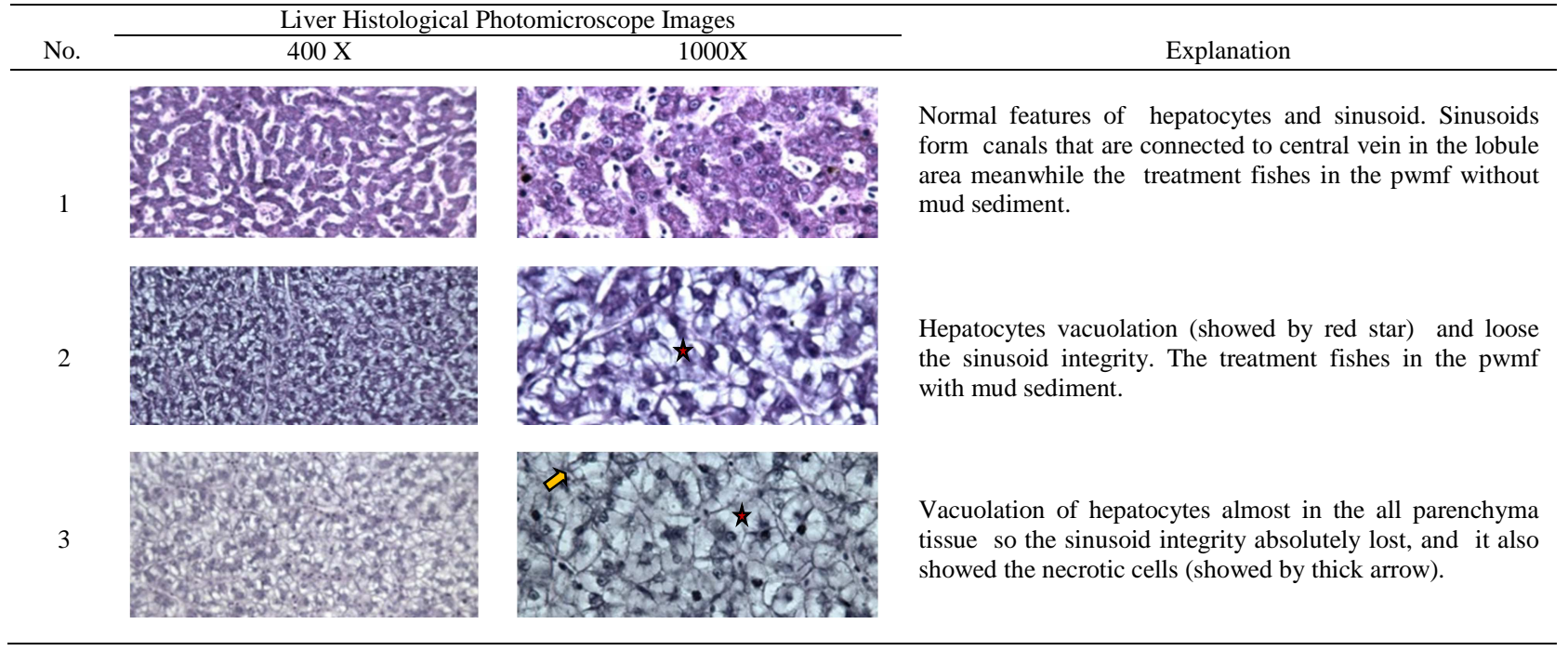

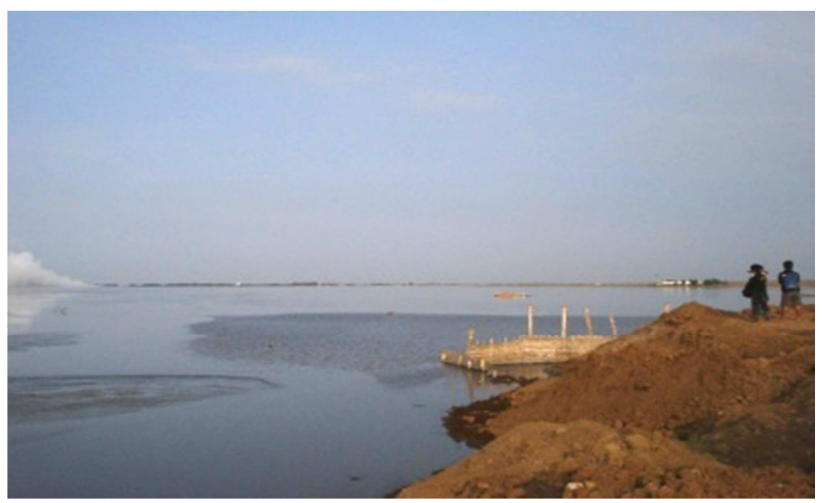

Fig. 1. Mud sampling location 
IPTEK, The Journal for Technology and Science, Vol. 21, No. 4, November 2010 